\title{
THE INDIAN STOCK MARKET AND POLITICAL CYCLES
}

\author{
Jayen B. Patel, Adelphi University, Garden City, New York, U.S.A.
}

\author{
dx.doi.org/10.18374/JIFE-20-3.3
}

\begin{abstract}
We examine the relationship between the Indian stock market and political cycles over the period of October 1999 to April 2019. First, we find Indian stock market returns are not statistically different during periods when the prime minister is from the left-leaning Indian National Congress or from the right-leaning Bharatiya Janata Party. Second, we find Indian stock market returns during any one particular year are not statistically different from other four years of the five-year Indian prime ministerial term. Third, we find Indian stock market generate high positive returns comparable to that of the U.S. stock market irrespective of political affiliation of the prime minister and the ruling party of the Indian government. We conclude Indian stock market generates high positive returns regardless if the control of the government is with the Indian National Congress or the Bharatiya Janata Party.
\end{abstract}

Keywords: Indian stock market, political cycles. Prime minister of India, Bharatiya Janata Party, Indian National Congress, Democrat premium, left-wing premium, presidential cycles, election cycles. 